\title{
Does the number of lymph nodes harvested reflect the width of lymphadenectomy in gastric carcinoma? Results of a prospective comparative study
}

\section{Gastrik kanserde çıkarılan lenf nodu sayısı lenfadenektomi genişliğini yansıtıyor mu? prospektive karşılaştırmalı çalışmanın sonuçları}

\author{
Atilla Kurt', Tugba Matlim², Oktar Asoglu
}

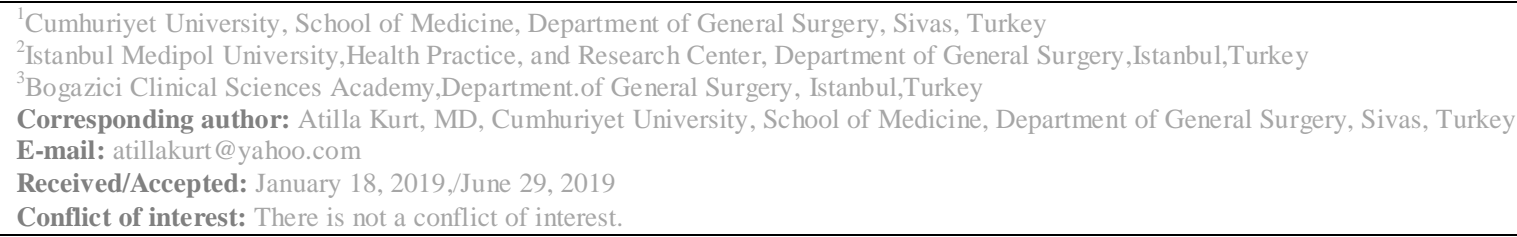

\section{SUMMARY}

Objective: The aim of this study was to evaluate the sufficiency of the surgical technique according to the extended lymph node dissection in gastric cancer patients (GCPs). We supported our findings with the determination of a number of lymph nodes (LNs) in lymph node stations with an autopsy performed on cadavers without any type of cancer.

Method: 55 GCPs were enrolled. Extended lymphadenectomy was performed on 23 autopsy cases as a comparative group. Total gastrectomy and D2 dissection were performed as the standard surgical approach.

Results: According to TNM classification, nine cases (18\%) were stratified to stage I, three (6\%) to stage II, $22(36 \%)$ to stage III, and 21 $(40 \%)$ to stage IV. The median number of excised LNs from the 55 cases was 47 (24-95), metastatic LNs were 15 (1-71) in patients. In the autopsy group, the median number was 72 (50-91). If D1 dissection had been performed instead of D2 dissection in the 55 cases, the median number of excised LNs would have been 24 (10-57), and metastatic LNs would have been 5 (1-45). If D1 dissection had been performed in the autopsy group, the median number of excised LNs would have been 36 (20-49).

Conclusions: The number of LNs harvested does not reflect the width of lymphadenectomy. D2 dissection must be performed stationary to achieve adequate extension of the lymphadenectomy. Possible skip metastasis and stage migration will also be reduced so that more efficient oncological results will be achieved.

Keywords: Gastric cancer, lymph node dissection, metastasis, lymph nodes
(D) Atilla Kurt
(D) Tuğba Matlim
(D) Oktar Asoğlu

ORCID IDs of the authors: A.K. 0000-0002-3649-6293 T.M. 0000-0001-9512-8848 O.A. 0000-0002-9147-1654 
Amaç: Bu çalışmanın amacı mide kanseri hastalarında genişletilmiş lenf nodu diseksiyonuna göre cerrahi tekniğin yeterliliğini değerlendirmektir. Bulgularımızı, lenf nodu (LN) istasyonlarında saptanan lenf nodu (LN) sayılarını, herhangi bir kanser türü olmayan kadavralar üzerinde yapılan otopsiler ile destekledik.

Yöntem: 55 mide kanseri hastası çalışmaya alındı. Genişletilmiş lenfadenektomi, 23 otopsi olgusunda karşılaştırmalı grup olarakyapıldı. Hastalara standart cerrahi yaklaşım olarak Total gastrektomi ve D2 disseksiyon uygulandı.

Bulgular: TNM sınıflamasına göre dokuz olgu (\% 18) evre I, üç (\% 6) evre II, 22 (\% 36) evre III ve 21 (\% 40) evre IV idi. 55 olguda çıkarılan LN'larının medyan sayısı 47 (24-95), metastatic LN'ları ise 15 (1-71) idi. Otopsi grubund amedyan say1 72 (50-91) idi. 55 olguda D2 diseksiyonu yerine D1 diseksiyonu yapılsaydı, eksize edilen LN'larının medyan sayısı 24 (10-57) ve metastatik LN sayıs1 5 (1-45) olacaktı. Otopsi grubunda D1 diseksiyonu yapılsaydı, eksize edilen LN'larının ortanca sayısı 36 (20-49) olacaktı.

Sonuç: Çıkarılan lenf nodlarının sayısı lenfadenektominin genişliğiniyansıtmamaktadır. Yeterli genişlikte lenfadenektomi yapılabilmesi için D2 disseksiyon istasyonel olarak yapılmalıdır. Olası skip metastaz ve evre kayması da böylelikle azaltılmış olacaktır. Böylece daha yeterli onkolojik sonuçlar elde edilecektir.

Anahtar sözcükler: Gastrik kanser, lenf nodu disseksiyonu, metastaz, lenf nodları

\section{INTRODUCTION}

The value of extended surgical dissection to remove the draining lymph nodes (LNs) has been controversial for over the years. Japanese surgeons routinely perform the more extended (D2) as opposed to the more limited (D1) lymph node dissection, reasoning that the tumor disseminates outwards in an orderly fashion through lymphatic channels from the stomach (Figure 1, 2). Therefore, extended lymph node dissection should improve both staging and longterm survival ${ }^{1-3 .}$ Several non-randomized studies from Western surgeons have also reported excellent survival results with D2 surgery when compared to contemporary reports on conventional surgery ${ }^{4-6}$. In contrast, randomized controlled trials have shown no evidence of survival benefit for D2 surgery, and it showed evidence of increased postoperative morbidity and mortality ${ }^{7-12}$. Two randomized controlled European trials that compared D1 dissection to D2 dissection failed to show any survival benefit for extended lymphadenectomy ${ }^{7-11}$. Lack of experience in terms of the surgical procedure and postoperative care were deemed the most obvious reasons for the poor outcome of extended lymphadenectomy ${ }^{13-15}$. The number of LNs harvested during surgery differs greatly between clinics and surgeons. Whether surgeon experience affects the number of LNs extracted, and whether the quality of the dissection varies between singlecenter and multicenter studies remain unclear. The removable lymph node number in the upper gastrointestinal tract and the factors influencing this number are currently unknown. The removable lymph node number in gastric cancer surgery signifies wide variability between surgeons and surgery departments.

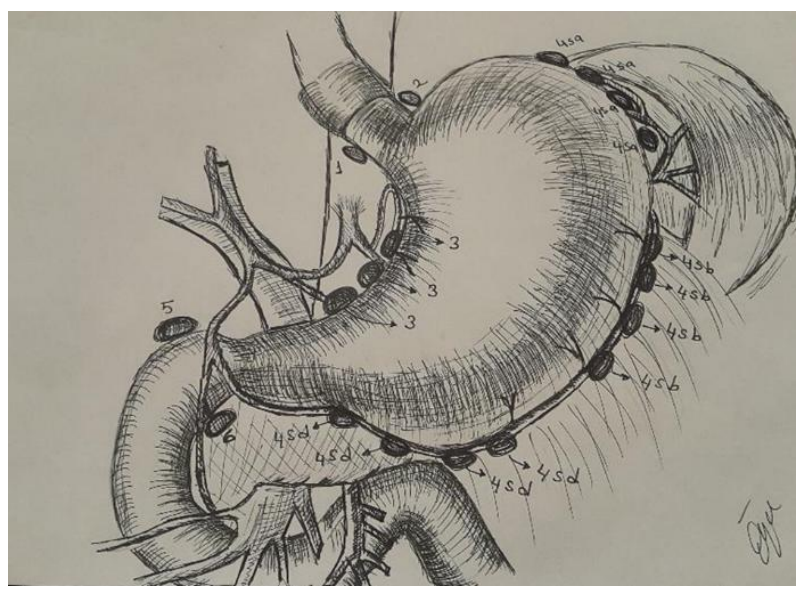

Figure 1: D1 lymph node stations in gastric cancer surgery

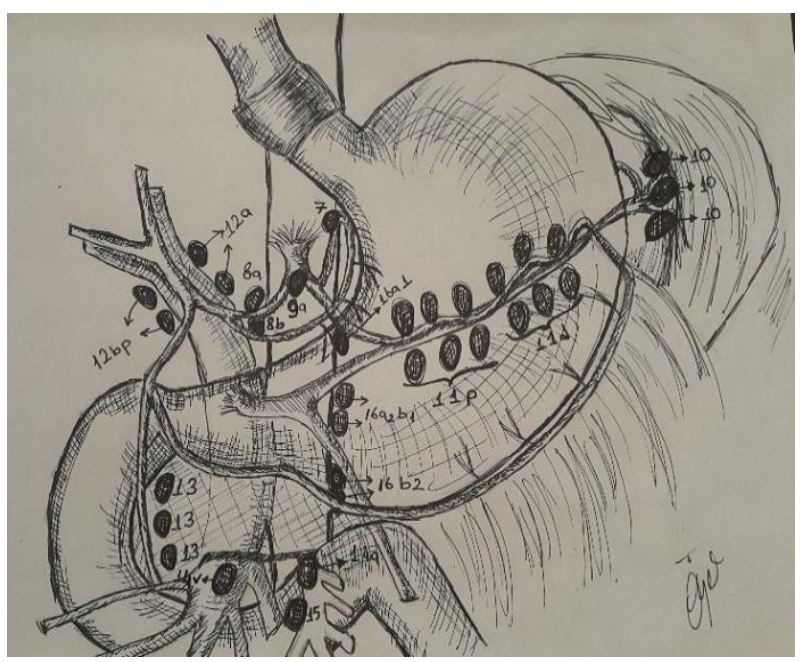

Figure 2: D2 lymph node stations in gastric cancer surgery

The purpose of the present study was to evaluate the sufficiency of the surgical technique according to the extended lymph node dissection (ELND) in gastric cancer patients (GCPs). Extended 
lymphadenectomy was performed according to the Japanese Research Society for Gastric Cancer (JRSGC) guidelines ${ }^{14}$. We supported our findings with the determination of the number of lymph nodes in lymph node stations with an autopsy performed on cadavers without any type of cancer.

\section{MATERIAL AND METHODS}

The prospective study design involved collecting data from 126 GCPs referred to the General Surgery Department of Istanbul University Medical Faculty between January 2006 and July 2009; 55 of these patients were enrolled in the study. Extended lymphadenectomy was performed on 23 fresh autopsy cases (comparative group). Ethical approval was obtained from the Istanbul University Medical Faculty Local Ethics Committee-2009/1822 and the Ethics Committee of the Forensic Medicine Institute of the Turkish Republic Justice Department-2009/547.

\section{Preoperative Evaluation}

Preoperative patient evaluation and staging included physical examination, complete blood count and biochemical parameters, chest X-ray, abdominal computed tomography (CT), and upper gastrointestinal endoscopy. Tumors were classified into three groups according to the predominant anatomical site: antrum, corpus, or cardia. GCPs were informed of the study and signed a consent form preoperatively.

\section{Inclusion and Exclusion Criteria}

Patients with a histologically confirmed diagnosis of gastric carcinoma were included if clinical data predicted that surgical resection would be curative. Patients were evaluated according to the American Society of Anesthesiologists classification. Those included were under 80 years of age with no serious respiratory, urinary, and/or cardiovascular insufficiency. Patients with remnant stomach cancer and/or concomitant tumor, and those who had previously undergone neoadjuvant chemotherapy or chemoradiotherapy were excluded.

Age, sex, body mass index (BMI), and cause of death were recorded for the comparative autopsy cases. Exclusion criteria included: intraabdominal or visceral malignancy, hematologic or lymphatic pathology, penetrating firearm or sharp object injury to the abdomen, previous abdominal surgery, and age under 16 or over 70 years.

The standard approach to patients with gastric carcinoma
All patients with a diagnosis of gastric carcinoma received consent forms preoperatively. Clinical staging was determined according to the tumor size, node status, metastasis (TNM) staging system $\left(6^{\text {th }}\right.$ Edition) ${ }^{17}$. (We designed this trial before publishing the $7^{\text {th }}$ edition). Surgical success and need for adjuvant therapy were evaluated by the Oncology Council, members of which were lecturers from the General Surgery, Pathology, and Oncology departments. Patients were followed-up every 3 months postoperatively.

\section{Surgical Technique}

For patients eligible for curative resection, total gastrectomy and extended lymphadenectomy were performed as we described in our previous study (18) The lymph nodes were excised and placed in numbered boxes by the same surgeon in the operating room. All samples were submitted for pathological examination.

\section{Autopsy dissection}

Lymph node dissection was performed on 23 cadavers to remove lymph nodes situated at stations $1-16$ according to the Japanese Research Society for Gastric Cancer (JRSCG) guidelines ${ }^{14}$. All stations were dissected, boxed, and numbered by the same surgeon. All samples were stored and submitted for pathological examination.

\section{Pathological Examination}

The fatty-fibrous tissues and the gastric specimens excised from the study group and the fatty-fibrous tissues excised from the autopsy cases were submitted to the Pathology Department of Istanbul University Medical Faculty. After fixation in formalin for $24 \mathrm{~h}$, tissue samples were taken from the specimens and coded lymph nodes for conventional histopathological assessment. The following data were collected: prognostic parameters including localization, diameter, invasion depth, histological type and degree of tumor differentiation, presence of vascular and perineural invasion including distance to proximal and distal surgical margins, number of lymph nodes removed from each station and number of metastatic lymph nodes. For the autopsy cases, the total number of lymph nodes at each station was recorded.

\section{Surgical Method}

The number of stational LNs excised, and the numbers of metastatic LNs were recorded for the study group, and the number of stational LNs excised was recorded for the autopsy cases. Furthermore, the number of LNs excised and the number of metastatic LNs was evaluated in both 
groups, assuming that $\mathrm{D} 1$ dissection (dissection of lymph node stations 1 to 6 ), modifying dissection A (dissection of station 7 in addition to stations 1 to 6) and modifying dissection $B$ (dissection of stations 7 to 9 in addition to stations 1 to 6 ) were performed for both groups. Additionally, the rate of metastatic LNs was evaluated according to tumor localization and T-stage in both study groups.

\section{Skip Metastasis}

The presence of lymph node metastasis in N2group (next level) stations and the absence of metastasis in perigastric stations (first level) (skip metastasis) were investigated according to histopathological findings. Similarly, skip metastasis rates were assessed in the study group, assuming that $\mathrm{D} 1$ dissection, modifying dissection $\mathrm{A}$, and modifying dissection $\mathrm{B}$ were performed.

\section{Stage migration (Will Rogers Phenomenon)}

The total number of LNs excised, and the number of metastatic LNs was re-evaluated assuming that D1 dissection, modifying dissection $\mathrm{A}$ and modifying dissection $\mathrm{B}$ were performed, and the cases were re-staged according to both the TNM and the $\mathrm{pN}$ (pathological lymph node) staging systems. Stage migration rates were evaluated to compare the findings with the present disease stages and $\mathrm{pN}$ stages.

\section{Surgical Mortality and Morbidity}

Any death occurring during the postoperative 30day follow-up was considered surgical mortality and any surgical complication that developed within that period was considered surgical morbidity. Surgical mortality and morbidity rates were evaluated. Potential parameters affecting mortality and morbidity were investigated.

\section{Statistics}

Statistical analysis was performed using SPSS version 16.0 for Windows (Statistical Package for Social Sciences, Inc. Chicago, IL; ABD for Windows 16.0). Student's t-test, Mann-Whitney U test, analysis of variance (ANOVA) and Chisquared tests were used to compare qualitative data and for demographic statistical analysis (mean standard deviation, frequency). The 95\% confidence interval (CI) was determined. A p value of $<0.05$ was considered statistically significant.

\section{RESULTS}

Demographic Findings

Fifty-five GCPs were included in the study group. The median age was 58 years (range 3180 years). Fourteen patients were female ( $25 \%)$, and 41 were male $(75 \%)$. Comorbidity was observed in $54 \%(n=33)$ of cases. Heart disease was present in 19 cases, respiratory disease in 4 cases, and both respiratory and heart disease in 7 cases.

\section{Harvested Lymph nodes}

The median number of lymph nodes excised from the 55 GCPs was 47 (24-95), the median number of metastatic LNs found was 15 (1-71). In the autopsy group, the median number was $72(50$ 91). The number of LNs harvested according to the JRSGC guidelines is presented in Table 1.

Frequency of lymph node metastasis by tumor localization

Gastric tumors located proximally metastasized mostly to stations $1,7,9,3$ and $2(59,55,50,44$ and $39 \%$, respectively), tumors located medially metastasized mostly to stations $3,8,9,4$ and 6 $(81,54,54,46$ and $46 \%$, respectively), tumors located distally metastasized mostly to stations 6 , $8,9,4$ and 3 (57, 48, 38, 38 and 33\%, respectively) and disseminated tumors metastasized mostly to stations $3,4,7$ and 9 (100, $80,80,100 \%$, respectively). 
Table 1: Median number of lymph nodes removed and the median number of tumor-positive lymph nodes in each station

\begin{tabular}{lcccc}
\hline Station & \multicolumn{2}{c}{ The median number of lymph nodes removed } & \\
Number & $\begin{array}{c}\text { Total number of } \\
\text { lymph nodes } \\
\text { harvested in the } \\
\text { study group }\end{array}$ & $\begin{array}{c}\text { Total number of } \\
\text { tumor-Metastatic } \\
\text { lymph nodes }\end{array}$ & $\begin{array}{l}\text { Total number of lymph } \\
\text { nodes harvested in the } \\
\text { autopsy group }\end{array}$ & $\mathrm{P}<0.05$ \\
Station 1 & $3(0-24)$ & $0(0-7)$ & $3(1-10)$ & 0.411 \\
Station 2 & $4(0-13)$ & $0(0-6)$ & $3(1-7)$ & 0.438 \\
Station 3 & $4(0-18)$ & $1(0-15)$ & $6(1-11)$ & 0.83 \\
Station 4 & $3(0-12)$ & $0(0-9)$ & $11(4-17)$ & 0.001 \\
Station 5 & $0(0-7)$ & $0(0-4)$ & $2(1-4)$ & 0.006 \\
Station 6 & $7(1-17)$ & $0(0-16)$ & $9(4-18)$ & 0.812 \\
Station 7 & $6(0-13)$ & $0(0-5)$ & $6(2-12)$ & 0.42 \\
Station 8 & $7(0-17)$ & $0(0-15)$ & $3(2-9)$ & 0.484 \\
Station 9 & $4(1-25)$ & $1(0-8)$ & $4(1-7)$ & 0.145 \\
Station 10 & $1(0-8)$ & $0(0-5)$ & $5(1-10)$ & 0.001 \\
Station 11 & $1(0-10)$ & $0(0-4)$ & $5(2-11)$ & 0.001 \\
Station 12 & $1(0-17)$ & $0(0-2)$ & $4(2-9)$ & 0.003 \\
Station 16 & $2(0-20)$ & $0(0-4)$ & $6(1-12)$ & 0.001 \\
\hline
\end{tabular}

How must many lymph nodes be excised for radical surgery?

If $\mathrm{D} 1$ dissection had been performed instead of $\mathrm{D} 2$ dissection in the 55 study cases, the median number of excised LNs would have been 24 (1057 ), and the median number of metastatic LNs would have been 5 (1-45). If D1 dissection had been performed in the autopsy group, the median number of excised LNs would have been 36 (2049). If D1 dissection had been performed instead of D2 dissection, at least 25 LNs would have been obtained, and the percentage of patients with less than 15 excised LNs would have been $7 \%$. In the autopsy group, the corresponding percentages were 96 and $0 \%$, respectively. If modifying dissection A had been performed for both groups, the percentage of cases with more than 25 excised LNs would have been $57 \%$ in the study group, and $96 \%$ in the autopsy group. If modifying dissection B had been performed, these percentages would have been 93 and $100 \%$, respectively. When the dissection techniques and the percentage of cases with more than 25 excised LNs were analyzed with regards to tumor localization, this percentage would have been $50 \%$ for tumors located in the upper $1 / 3$ after D1 dissection, $72 \%$ after modifying dissection $\mathrm{A}$, and $98 \%$ after modifying dissection B. The percentage of LNs removable by each dissection technique is shown in Table 2 . 
Table 2: Ratio of lymph nodes removed by dissection type

\begin{tabular}{lcccc}
\hline & \multicolumn{3}{c}{ Dissection type } \\
& D1dissection & Modified & Modified & D2 dissection \\
& $(\%)$ & Dissection A (\%) & Dissection B (\%) & $(\%)$ \\
Patient group & & $\% 43$ & $\% 7$ & 2 \\
$<25$ lymph node & $\% 49$ & $\% 0$ & $\% 0$ & 0 \\
$<15$ lymph node & $\% 7$ & $\% 57$ & $\% 93$ & 98 \\
$\geq 25$ lymph node & $\% 51$ & & & 0 \\
Autopsy group & & $\% 4$ & $\% 0$ & 0 \\
$<25$ lymph node & $\% 4$ & $\% 96$ & $\% 100$ & 100 \\
$<15$ lymph node & $\% 0$ & $\% 96$ & & \\
$\geq 25$ lymph node & & & & 0 \\
\hline
\end{tabular}

\section{Skip metastasis}

Skip metastasis was found in four patients (7\%). Skip metastasis was only affected by the number of lymph nodes retrieved: the probability of skip metastasis increased as the number of LNs retrieved decreased $(p<0.0001)$. The effect of patient demographics and tumor characteristics on skip metastasis is presented in Table 3 . The results from the study group showed that the probability of skip metastasis decreased as the dissection was expanded (Table 3 ).

Table 3: Effect of patient demographics and tumor characteristics on skip metastasis

\begin{tabular}{lccc}
\hline Patient and tumor-related factors & Skip metastasis-negative & Skip metastasis-positive & $\mathrm{P}<0.05$ \\
Age & 13 & 1 & 0.983 \\
& 38 & 3 & 0.85 \\
BMI $\left(\mathrm{kg} / \mathrm{m}^{2}\right)$ & 23.7 & 24.4 & 0.06 \\
Tumor diameter $(\mathrm{cm})$ & 1.5 & 1 & \\
Tumor stage & & 0 & 0.878 \\
T1 & 4 & 1 & \\
T2 & 17 & 3 & \\
T3 & 30 & 0 & \\
T4 & 0 & & 0.806 \\
Nodal status & & 0 & \\
N0 & 9 & 1 & \\
N1 & 15 & 0 & 0.001 \\
N2 & 9 & 3 & \\
N3 & 18 & 38 & \\
Number of lymph nodes retrieved & 51 & & \\
\hline
\end{tabular}

BMI: Body mass index 
Stage migration

Stage migration was observed in 18 study group cases $(33 \%)$. When analyzed in terms of the $\mathrm{pN}$ stage, stage migration was observed in 16 cases (30\%). When examined according to dissection technique, stage migration was observed in $24 \%$ of the cases with modifying dissection A and $2 \%$ with modifying dissection $\mathrm{B}$.

No tumor-related variables affected stage migration in a statistically significant manner; however, the number of metastatic LNs excised from stations 7, 8 and 9 affected stage migration significantly $(\mathrm{p}<0.05)$, (Table 4).

Postoperative Mortality and Morbidity

Postoperative mortality occurred in two cases (3.6\%): one patient died of sudden respiratory failure while in intensive care 7 days postoperatively, and one patient died of pneumonia, pleural effusion, and acute respiratory distress syndrome 20 days after surgery. Morbidity occurred in 13 cases (24\%). Pneumonia (14\%) was a common cause of morbidity. Two cases underwent surgery for intraabdominal bleeding: in one of the patients, despite the lack of any active bleeding focus, long-term antibiotic use led to coagulopathy, while in the other patient bleeding from the splenic capsule led to splenectomy. Anastomotic leakage was observed in one case which required total parenteral nutrition and percutaneous drainage. The intraabdominal collection was observed in three cases. In two of them, percutaneous drainage was performed under CT guidance. The other patient who was ineligible for drainage was followed up with antibiotic therapy. No patient- or tumor-related factors were found to affect morbidity.

Table 4: The effect of stational metastatic lymph nodes to the stage migration

\begin{tabular}{llll}
\hline & \multicolumn{2}{c}{ Stage Migration } \\
Stations & $\begin{array}{l}\text { Number of patients without } \\
\text { stage migration (n) }\end{array}$ & $\begin{array}{l}\text { Number of patients with } \\
\text { stage migration (n) }\end{array}$ & $\mathrm{P}<0.05$ \\
1 no Metastasis (-) & 23 & 10 & 0.905 \\
Metastasis (+) & 15 & 7 & \\
2 no Metastasis (-) & 32 & 11 & 0.106 \\
Metastasis (+) & 6 & 6 & \\
3 no Metastasis (-) & 19 & 7 & 0.545 \\
Metastasis (+) & 19 & 10 & \\
4 no Metastasis (-) & 23 & 9 & 0.598 \\
Metastasis (+) & 15 & 8 & \\
5 no Metastasis (-) & 27 & 14 & 0.374 \\
Metastasis (+) & 11 & 3 & \\
6 no Metastasis (-) & 22 & 8 & 0.456 \\
Metastasis (+) & 16 & 9 & \\
$\mathbf{7 n o}$ Metastasis (-) & $\mathbf{2 5}$ & $\mathbf{7}$ & \\
Metastasis (+) & $\mathbf{1 3}$ & $\mathbf{1 0}$ & \\
$\mathbf{8}$ no Metastasis (-) & $\mathbf{2 4}$ & $\mathbf{6}$ & $\mathbf{0 . 0 4 2}$ \\
Metastasis (+) & $\mathbf{1 4}$ & $\mathbf{1 1}$ & \\
$\mathbf{9}$ no Metastasis (-) & $\mathbf{2 3}$ & $\mathbf{4}$ & \\
Metastasis (+) & $\mathbf{1 5}$ & $\mathbf{0 . 0 1 1}$ \\
10 no Metastasis (-) & 32 & 13 & 0.492 \\
Metastasis (+) & 6 & 4 & \\
11 no Metastasis (-) & 30 & 14 & 0.77 \\
Metastasis (+) & 8 & 3 & \\
12 no Metastasis (-) & 36 & 13 & 0.245 \\
Metastasis (+) & 2 & 4 & 0.284 \\
16 no Metastasis (-) & 35 & 14 & \\
Metastasis (+) & 3 & 3 & \\
\hline
\end{tabular}

\section{DISCUSSION}

Regardless of tumor location, the general tendency is to extract as many LNs as possible through complete resection and extended lymph node dissection. The invasion depth of the tumor, the existence of lymph node metastasis, the number of LNs extracted, and the existence of 
distant metastasis are the most important factors in determining prognosis ${ }^{19-21}$.

Noguchi et al. ${ }^{22}$ and Maruyama et $_{\text {al. }}{ }^{23}$ showed that the metastatic lymph node count increases when the lymph node dissection width is expanded. Therefore, the number of LNs harvested is the best parameter known at present to evaluate the radicality of the surgical procedure. Studies addressing this issue and median lymph node counts are shown in Table 5 7,24-28. The median number of LNs extracted varies between 55 and 74 in Eastern studies and between 17 and 45 in Western studies.

Although increased lymph node dissection width affects the metastatic lymph node counts, a key issue that needs to be studied further is the physiological number of LNs thought to be located in the human gastrointestinal tract ${ }^{18,29-31}$.

In contemporary gastric cancer staging, the location and number of LNs and the number of metastatic LNs detected are important parameters in the pathological evaluation of specimens. The minimal number of LNs required for adequate TNM staging is 15 . Siewert et al. ${ }^{5}$ categorized dissection procedures according to the number of LNs extracted: D2 dissection (> 25) and D1 dissection $(<25)$. Siewert et al. ${ }^{5}$ showed that the number of lymph nodes extracted correlated with the extent of dissection, which is now accepted worldwide.

In the present study, 25 or more LNs were extracted from $51 \%$ of the living cases; whereas the percentage was $96 \%$ in the autopsy group, even when D1 dissection (stations1-6) was performed instead of D2 dissection. If D1 dissection only had been performed in our study group, the percentage of patients from whom less than 15 LNs was extracted would have been $7 \%$ ( $2 \%$ for the autopsy group). Although the number of excised LNs is more useful for the TNM classification $(29,30)$, we concluded that stationary lymph node dissections might be more reliable than the extracted number of LNs in gastric cancer surgical treatment.

Table 5: Median numbers of lymph nodes removed

\begin{tabular}{|c|c|c|c|c|c|}
\hline Study & year & Operation & $\begin{array}{l}\text { Patient number } \\
\text { (n) }\end{array}$ & $\begin{array}{l}\text { Lymph node number } \\
\text { (median) }\end{array}$ & $\begin{array}{c}\text { Annual patient } \\
\text { number (n) }\end{array}$ \\
\hline \multicolumn{6}{|l|}{ Single-center study } \\
\hline $\operatorname{MSKCC}(\mathrm{I})^{21}$ & 2000 & D2 & 154 & $30(15-45)$ & 73 \\
\hline Present study (patient group) & 2009 & $\mathrm{D} 2+\mathrm{PAN}$ & 55 & $47(24-95)$ & 22 \\
\hline $\mathrm{YCU}(\mathrm{II})^{21}$ & 2000 & D2 & 194 & $55(28-82)$ & 29 \\
\hline Present study (autopsy group) & 2009 & $\mathrm{D} 2+\mathrm{PAN}$ & 23 & $72(50-91)$ & - \\
\hline \multicolumn{6}{|l|}{ Multicenter study } \\
\hline $\operatorname{MRC}(\mathrm{III})^{5}$ & 1996 & D2 & 200 & 17 & 1.5 \\
\hline $\begin{array}{l}\text { Netherland gastric cancer group } \\
\text { (Bonenkamp, 1995) }\end{array}$ & 1995 & D2 & 331 & $26(0-105)$ & 1 \\
\hline PGCSG (IV) ${ }^{22}$ & 2007 & D2 & 134 & $28(25-31)$ & 5.5 \\
\hline $\operatorname{IGCSG}(\mathrm{V})^{23}$ & 1997 & D2 & 118 & $39(22-89)$ & 6 \\
\hline GGCS (VI) ${ }^{24}$ & 1998 & D2 & 1096 & $45(24-58)$ & 19.2 \\
\hline JCOG (VII) ${ }^{25}$ (Group A) & 2004 & D2 & 263 & $54(14-161)$ & 7 \\
\hline JCOG 9501 (Group B) & 2004 & $\mathrm{D} 2+\mathrm{PAN}$ & 260 & $74(30-235)$ & 7 \\
\hline
\end{tabular}

I: MSKCC: Memorial Sloan-Kettering Cancer Center;II: YCU: Yokohama City University; III: MRC: Medical Research Council; IV: PGCSG: Polish Gastric Cancer Study Group; V: IGCSG: İtalian Gastric Cancer Study Group;VI: GGCS: German Gastric Cancer Study Group; VII: Japanese Clinic Oncology Group. 
In early-stage tumors and in high-risk cases, in which lymphadenectomy is precluded by poor general status, the percentage of patients in whom more than 25 lymph nodes were detected was $57 \%$ with modified dissection $\mathrm{A}$, whereas with modified dissection B that percentage was $93 \%$. When subgroup analysis was performed according to tumor location, the percentages observed were $50 \%$ for D1 dissections, $72 \%$ for modified dissection $\mathrm{A}$, and $98 \%$ for modified dissection $\mathrm{B}$ in the upper $1 / 3$ of placed tumors. In median placed tumors, the same percentages were $95 \%$, $62 \%$, and $100 \%$ respectively, lower one thirdplaced tumors, and those were $46 \%, 72 \%$ and 95\% for each technique applied. Modified dissection $\mathrm{B}$ can be performed when extended lymphadenectomy is considered risky due to poor general health status. Therefore, stational dissection must depend on tumor location and on the $\mathrm{T}$ stage determined preoperatively. Lymph node counts determined through pathological examination reflect the radicality of operation.

Another important issue in gastric cancer staging skipped metastasis. Skip metastasis is defined as the invasion of the second-tier LNs by the tumor while the first-tier LNs remain clear. Published gastric cancer studies report skip metastasis ratios between $2.5 \%$ and $16.7 \%$ (34-37). Park et al. ${ }^{34}$ examined 589 cases retrospectively and reported skip metastasis in $2.4 \%$ of cases. Saito et al. ${ }^{37}$ examined 313 cases retrospectively and reported skip metastasis in $6.7 \%$ of cases. In both studies, skip metastasis was detected more frequently at stations 7, 8 and 9 than at stations 10 and 11. Park et al. ${ }^{34}$ concluded that the number of LNs extracted affected the occurrence of skip metastasis considerably. In our study, the results from the study group showed that the probability of skip metastasis decreased as the dissection was expanded (Table 3). Skip metastasis was observed in $7 \%$ of cases, and the most frequent occurrence of skip metastasis was at the $8^{\text {th }}$ station. The number of LNs extracted was the only variable: the lower that number, the higher the occurrence of skip metastasis ( $p<0.001$ ). In addition, skip metastasis was eliminated completely by D2 dissection and was reduced by up to $75 \%$ by modified dissection.

Extended lymph node dissection also influences stage migration. Stage migration is defined as the displacement of a fixed value used in a study due to a different surgical intervention or classification included in the study and, thus, results in significant alterations in survival outcome and disease staging. Bunt et al. ${ }^{38}$ reported a stage migration rate of approximately $30 \%$ when D1 dissection was performed instead of D2 dissection. In our study, the stage migration rate was $33 \%$. Stage migration was detected in $4 \%$ of stage 1 cases, $15 \%$ of stage 2 cases, and $14 \%$ of stage 3 cases, and was shifted further when D2 dissection was performed. Stage migration ratios were assessed by dissection type with $\mathrm{pN}$ staging and were as follows: $30 \%$ with D1 dissection, $24 \%$ with modified dissection A, and $9 \%$ with modified dissection $\mathrm{B}$; with TNM staging, the corresponding percentages were $33 \%, 24 \%$, and $2 \%$, respectively. In our study group, significant stage migration was observed at stations 7,8 , and 9, where metastatic LNs were detected. Hence, reduced stage migration, which can be accomplished by extended lymph node dissection, would help improve postoperative treatment options and survival rates. Moreover, for critical patients lacking the physical endurance required for extended lymph node dissection, skip metastasis and stage migration can be reduced remarkably by performing $\mathrm{D} 1+\mathrm{B}$ dissection (dissection of stations 8,7 and 9). Therefore, if D2 dissection cannot be performed, modified dissection B may be a suitable alternative.

\section{CONCLUSION}

The number of LNs harvested does not reflect the width of lymphadenectomy. D2 dissection must be performed stationary to achieve adequate extension of the lymphadenectomy. Possible skip metastasis and stage migration will also be reduced so that more literal oncological results will be achieved.

\section{Acknowledgment}

Atilla Kurt was a clinical fellow in the General Surgery Department of Istanbul Medical Faculty during the study.All the other authors were surgeons in the General Surgery Department of Istanbul Medical Faculty during the study.

Ethics Committee Approval: Ethical approval was obtained from the Istanbul University Medical Faculty Local Ethics Committee2009/1822 and the Ethics Committee of the Forensic Medicine Institute of the Turkish Republic Justice Department-2009/547.

Author Contributions: Conceived and designed the experiments or case: OA, TM. Performed the experiments or case: OA, TM, KRS. Analyzed the data: AK. Wrote the paper: AK.

Conflict of Interest: No conflict of interest was declared by the authors. 
Financial Disclosure: The authors declared that this study had received no financial support

\section{REFERENCES}

1. Mc Culloch P, Nita ME, Kazi H, GamaRodriques J. Extended versus limited, lymph nodes dissection technique for adenocarcinoma of the stomach. Cochrane Database of Systematic Reviews. 2003; (4) CD 001964 Cochrane Database Syst Rev.

2. Quadri HS, SmagloBG,Morales SJ, et al. Gastric adenocarcinoma: Multimodal Approach. Front Surg 2017; 3: 4: 42.

3. Wang H, Xing XM, Ma LN, et al. Metastatic lymph node ratio and Lauren classification are independent prognostic markers for survival rates of patients with gastric cancer. Oncol Lett 2018;15:6:8853-62.

4. Pacelli F, Doglietto GB, Bellantone R, et al. Extensive versus limited lymph node dissection for gastric cancer: a comparative study of 320 patients. Br J Surg 1993; 80: 1153-56.

5. Siewert JR, Böttcher K, Roder J, Busch R, Hermanek P, Meyer HJ. Prognostic relevance of systemic lymph node dissection in gastric carcinoma. German Gastric carcinoma Study Group. Br J Surg 1993; 80: 1015-18.

6. Sue-Ling HM, Johnston D, Martin IG, et al. Gastric cancer: a curable disease in Britain BMJ 1993; 307: 591-96.

7. Cuschieri A, Fayers $\mathrm{P}$, Fielding $\mathrm{J}$, et al. Postoperative morbidity and mortality after D1 and D2 resections for gastric cancer: preliminarty results of the MRC randomised controlled surgical trial. Lancet 1996; 347: 99599.

8. Cuschieri A, Weeden S, Fielding $\mathrm{J}$, et al. Patients survival after D1 and D2 resections for gastric cancer: long-term results of the MRC surgical trial. Brit J Cancer 1999; 79: 1522-30.

9. Robertson CS, Chung SC, Woods SD, et al. A prospective randomised trial comparing R1, subtotal gastrectomy with R3 total gastrectomy for antral cancer. Ann Surg 1994; 220: 176-182.

10.Bonenkamp JJ, Songun I, Hermans J, et al. Randomised comparison of morbidity after D1 and D2 dissection for gastric cancer in 996 Dutch patients. Lancet 1995; 345: 745-48.

11.Bonenkamp JJ, Hermans J, Sasako M, Van de Velde CJ. Extended lymph node dissection for gastric cancer. NEJM 1999; 340: 908-58.
12.Dent DM, Madden MV, Price SK. Randomised comparison of R1 and R2 gastrectomy for gastric carcinoma. Br J Surg. 1988; 75: 110-12.

13.Wu CW, Hsiung CA, Lo SS, Hsieh MC, Shia LT, Whang-Peng J. Randomised clinical trial of morbidity after D1 and D3 surgery for gastric cancer. Br J Surg 2004; 91: 281-87.

14.Dequili M, Sasako M, Calgaro M, et al. Italian gastric cancer study group. Morbidity and mortality after D1 and D2 gastrectomy for cancer: interm analysis of the italian gastric cancer study group (IGCSG) randomised surgical trial. Eur J SurgOncol 2004; 30: 303-08.

15.Sasako M, SanoT, Yamamoto S, et al. D2 lymphadenectomy alone or with para-aortic nodal dissection for gastric cancer. N Eng J Med 2008; 359: 453-62.

16.Japanese Gastric Cancer Association (JGCA). Japanese classification of gastric carcinoma- $2^{\text {nd }}$ English Edition. Gastric cancer 1998; 1:10-24.

17.Sobin LH, Wittekind C. International Union Against Cancer (UICC) TNM classification of malignant tumours [M]. 6th edition. New York: Wiley, 2002: 70-72.

18.Asoglu O, Matlim T, Kurt A, et al. Guidelines for Extended lymphadenectomy in gastric cancer: A prospective comparative study. AnnSurgOncol 2013; 20: 218-25.

19. Maruyama K. The most important prognostic factors for gastric cancer patients: A study Using Univariate and Multivariate analysesScand $\mathbf{J}$ Gastroenterol 1988; 22: 63-68.

20.Asoglu O, Karanlik H, Parlak M, et al. Metastatic lymph node ratio is an independent prognostic factor in gastric cancer. Hepatogastroenterology 2009; 56: 908-13.

21.Degiuli M, De Manzoni G, Di Leo A, et al. GAstric cancer: Current status of lymph node dissection. World J Gastroenterol 2016; 22: 10: 2875-93.

22.Noguchi Y, Imada T, Matsumoto A, Coit DG, Brennan MF. Radical surgery for gastric cancer. Cancer 1989; 64: 2053-62.

23. Maruyama K, Gunven P, Okabayashi K, Sasako M, Kinoshita T. Lymph node metastasis of gastric cancer. Ann Surg. 1989; 210: 596-602.

24.Noguchi Y, Yoshikawa T, Tsuburuya A, Motohashi H, Karpeh MS, Brennah MF. Is gastric cancinoma different between Japan and the United States. Cancer 2000; 89: 2237-46 
25.Kulig J, Popiela T, Kolodziejczyk P, Sierzega M, Szczepanik A; Polish Gastric Cancer Study Group. Standart D2 versus extended D2 lymphadenectomy for gastric cancer: an interim safety analysis of a multicenter, randomised clinical trial. Am J Surg 2007; 193: 10-15.

26.Dequili M, Sasako M, Ponzetto A, et al. Extended lymph node dissection for gastric cancer: results of a prospective multi-center analysis of morbidity and mortality in 118 consecutive patients. Eur J of SurgOncol 1997; 23: 310-14.

27. Siewert JR, Böttcher K, Stein HJ, Roder JD. Relevant prognostic factors in gastric cancer: ten-year results of the German Gastric Cancer Study. Ann Surg 1998; 228: 449-61.

28.Sano T, Sasako M, Yamamoto S, et al. Gastric cancer surgery: morbidity and mortality results from a prospective randomised controlled trial comparing D2 and extended para-aortic lymphadenectomy. Japan clinical oncology group study 9501. J ClinOncol 2004; 22: 276773.

29.Bonenkamp JJ, Hermans J, Sasako M, van de Velde CJ. Quality control of lymph node dissection in the Dutch randomized trial of D1 and D2 lymph node dissection for gastric cancer. Gastric Cancer 1998; 1: 152-59.

30.Bunt AM, Hermans J, van de Velde CJ, et al. Lymph node retrieval in a randomized trial on Western-type versus Japanese type surgery in gastric cancer. J ClinOncol 1996; 14: 2289-99.

31.Wagner PK, Ramaswamy A, Rüschoff J, Schmitz-Moormann P, Rothmund M. Lymph node counts in the upper abdomen: anatomical basis for lymphadenectomy in gastric cancer. $\mathrm{Br}$ J Surg 1991; 7 8: 825-27.
32.Aurello P, D'Angelo F, Rossi S, et al. Classification of lymph node metastases from gastric cancer: comparison between $\mathrm{N}$-site and $\mathrm{N}$-number systems. Our experience and review of the literature. Am J Surg 2007; 73: 359-66.

33.Kodera Y, Yamamura Y, Shimizu Y, et al. The number of metastatic lymph nodes: a promising prognostic determinant for gastric carcinoma in the latest edition of the TNM classification. $\mathbf{J}$ Am CollSurg 1998; 187: 597-603.

34.Park SS, Ryu JS, Min BW, et al. Impact of skip metastasis in gastric cancer. Anz J Surg 2005; 75: 645-49.

35.Kikuchi S, Kurita A, Natsuya K, et al. First dranaige lymph node(s) in gastric cancer: analysis of the topographical pattern of lymph node metastasis in patient with pN1 tumors, Anticancer Res 2003; 23: 601-04.

36. Arai K, Iwaski Y, Takahashi T. Clinicopathological analysis of early gastric cancer with solitary lymph node metastasis. Br J Surg 2002; 89: 1435-37.

37. Saito H, Tsujinati S, Ikequchi M. Clinical signifiance of skip metastasis in patients with gastric cancer. Gastric Cancer 2007; 10: 87-91.

38.Bunt AM, Hermans J, Smit VT, et al.Surgical pathologic stage migration confounds comparisons of gastric cancer survival rates between Japan and western countries. J of Clin Oncol 1995; 13: 19-25. 